\title{
The challenges of interdisciplinary education and its application on teaching ergonomics
}

\author{
Letícia Holtz Barbosa ${ }^{\mathrm{a}, *}$ and Maria Helena Câmara Pinheiro ${ }^{\mathrm{b}}$ \\ ${ }^{a}$ Physiotherapy Department, Centro Universitário Barão de Mauá, Rua Iguape,48, CEP:14090-092, Ribeirão \\ Preto, SP, Brazil \\ ${ }^{\mathrm{b}}$ Psycology Department, Universidade de Ribeirão Preto - UNAERP, Av. Costábile Romano, 2201, CEP:14096- \\ 900, Ribeirão Preto, SP, Brazil
}

\begin{abstract}
The education in Brazil is still strongly based on traditional teaching methods that reinforce a passive attitude of the student. Despite the educational guidelines indicate the need for more liberating and interdisciplinary methodologies, there are few actions for change. Within this context, interdisciplinary appears as an important tool to help the creation of a new thinking in education, proposing the connection between the parts of an area of knowledge. In this way leading the student to develop a more critical and reflective thinking about the reality of the community where he lives. Being understood ergonomics as a scientific discipline that looks for the interactions among humans and other elements of a system in order to optimize human well-being and overall system performance, interdisciplinary has become essential in this process. The aim of this study was to discuss the educational foundations of interdisciplinarity and their applicability in the teaching of ergonomics in the context of Brazil.
\end{abstract}

Keywords: Problem-based learning, higher education, interdisciplinarity, Ergonomics, Brazil.

\section{Introduction}

The education in Brazil is still strongly based on traditional teaching methods, so that knowledge is passed already prepared and ready by the teacher, thus emphasizing the adoption of a passive attitude of the student [6].

This statement represents what is called as "banking education" by Freire [6], symbolizing the traditional teaching methods, based on memorization, repetition, without the student realize the meaning of information. The prevailing thought is that the teacher has the knowledge and on the other hand the student knows nothing. It's supposed that the learner is unable to take control of himself, and should be led by people who know more than him.

Thus, this system is centered on the figure of the teacher holding the autonomy of knowledge, generating repetitive strategies, usually with lectures, and therefore creating a unilateral flow of communication, hindering the development of critical thinking by the learner. Most of the time the student assimilates what he is exposed, without question [17]. Given this context, education is seen as an act of depositing information in student's memory, hence the derivation of the term.

So, the traditional teaching, stimulates the formation of a passive student, that stores concepts and is unprepared to deal with practical issues, related to the reality he lives in. Educators and students are on the same context since, in this distorted view of education, there is no creativity, no transformation, there is no knowledge [6].

All this context is directly reflected in the newly formed professional, which often finds difficult to solve the most demanding market requirements [13]. Within this context, interdisciplinary appears as an important tool to help the creation of a new thinking in education, proposing the connection between the parts of an area of knowledge.

*Corresponding author. E-mail: lh_barbosa@yahoo.com.br 
There are several theories and concepts involved in defining interdisciplinary. In this study was used the idea of interdisciplinarity as the interaction between two or more disciplines, which may range from a simple communication of ideas to the mutual integration of the concepts of education and research [5].

In this way, interdisciplinary lead the student to develop a more critical and reflective thinking about the reality of the community where he lives. Being understood ergonomics as a "scientific discipline concerned with the understanding of interactions among humans and other elements of a system, and the profession that applies theory, principles, data and methods to design in order to optimize human well-being and overall system performance"[9], interdisciplinary has become essential in this process.

Looking for these points, is teaching of ergonomics in Brazil based on the educational practices of interdisciplinary? Which strategy could be used to introduce interdisciplinary as a method of teaching ergonomics?

So, the aim of this study was to discuss the educational foundations of interdisciplinarity and their applicability in the teaching of ergonomics in the context of Brazil.

\section{Method}

This study refers to a review on interdisciplinary applied to ergonomics. The bibliography was obtained through electronic and print research, regardless of the time of publication. The papers were served on the international and domestic data basis: PubMed, Lilacs, Scielo-Brasil and BIREME. The keywords used to search were: CompetencyBased Education; Higher Education; Problem-Based Learning; Ergonomics; Attitudes, Practice, Interdisciplinary Research; Interdisciplinary Communication.

\section{Findings}

This review showed that the interdisciplinary is a concept used in many documents and aims of teaching plans, however ineffective in practice. Few studies had found interdisciplinary education models and results in universities.

Among the articles that describe this practice in Brazil, it was more common found on medicine courses [1]. No study described this methodology in discipline of ergonomics neither specialization. So the difficulties and needs for the implementation of systems based on critical and reflective professional were raised.

\section{Discussion}

For several reasons, the liberating education is not yet a reality in most cases of the courses in the area of health in Brazil.

The insertion of interdisciplinarity in the educational context involves a series of actions and presents itself as a complex process. This insertion is complex because it needs to join the institution, faculty and students [18], bringing many challenges such as break traditional models of teaching and training health professionals with skills that enable them to recover the dimension of care and the relationship between human [4].

Among the difficulties for the implementation of interdisciplinary as a teaching method in Brazil, the following points: needs to form an interdisciplinary group of professors [5]; changes in the education system and structures of pedagogical universities[8]; teacher training in several areas of knowledge without the dominance of the educational aspects involved in educational activity [16]; teachers necessity to develop a set of skills that qualify them for teaching these competences and dimensions: epistemological, pedagogical and social policy[14].

But the difficulties of change should not inhibit the educators. Many actions have been made in individual areas or small groups in an attempt to awaken to this need. It is important to begin the processes with traditional curricular structures for the purpose of the changes be made gradually and consistently.

The analysis from case studies raise some possible directions in order to implement changes in teaching methods $[2,3,7,15,16]$. They are:

- The practice as a basis for theoretical reflection;

- The use of basic sciences as an ongoing complement of the development of professional contents;

- Lecture as a possible tool for learning;

- Teaching focused on the needs of the community or company;

- To promote pro active posture in the students;

- Assessment tools aimed to capture the knowledge, skills and attitudes of students 
with primary goal of guiding corrections needed trajectories;

- Change in the characteristics of the subjects, directing the student to more concrete experience of simulated or for scientific initiation;

- Development of courses in closely with the needs of the labor market, or using their own manufacturing facilities as a classroom;

- Overhaul of lab activities by proposing problems whose solutions are unknown even by their own teacher, introducing a question of actual research and not simulated;

- Using an exercise program by replacing the single final exam.

Although the items mentioned generate major challenges and complex deployment to the academic community, the interdisciplinary may be included in the Brazilian universities. This input is extremely important in bringing an interdisciplinary approach based on logical, critical and reflective development about the professional's performance. This is an essential point in the formation of the ergonomist, which treat complex problems involving health, comfort and worker safety.

\section{References}

[1] Aguiar, A.C. (2001). Implementando as novas diretrizes curriculares para a educação médica: o que nos ensina o caso de Harvard? Interface - Comunic, Saúde, Educ., v.5, n.8, p.161-166.

[2] Chamliar, H.C. (2003). Docência na universidade: professores inovadores na USP. Cadernos de Pesquisa, n. 118, p.41-64.

[3] Chun, R.Y.S. \& Bahia, M.M. (2009). O uso do portfólio na formação em fonoaudiologia sob o eixo da integralidade. Rev. CEFAC, v.11, n.4.

[4] Cyrino, E.G. \& Toralles-Pereira,M.L. (2004). Trabalhando com estratégias de ensino-aprendizado por descoberta na área da saúde: a problematização e a aprendizagem baseada em problemas. Cad. Saúde Pública, v.20, n.3, p.780-788.
[5] Fazenda, I.C.A. (1979). Integração e interdisciplinaridade no ensino brasileiro: efetividade ou ideologia. São Paulo: Edições Loyola.

[6] Freire, P. (1987). Pedagogia do Oprimido. $17^{\mathrm{a}}$ ed. Rio de Janeiro: Paz e Terra.

[7] Galindo, A.G.; Ribeiro, F.C. \& Silva, M.C. (2010). Integração em bloco de disciplinas como alternativa para implementação de estratégias interdisciplinares. In: I Seminário de Interdisciplinaridade do Centro Superior de Ensino do Amapá, Macapá, Resumos... Disponível em: $<$ http://www.ceap.br/artigos/ART10022010190833.pdf>. Acesso em: 15 nov. 2010

[8] Hass, C.M. (2007) Interdisciplinaridade: uma atitude docente. Olhar Docente, 1, pp. 179-193. Retrieved from http://redalyc.uaemex.mx/pdf/684/68410110.pdf.

[9] IEA (International Ergonomics Association). In The Discipline of Ergonomics. 2000. Retrieved from http://www.iea.cc/01_what/What\%20is\%20Ergonomics.html.

[10]Ito, A.M.Y. et al. (2010). As transformações curriculares dos cursos do CCS/UEL no contexto da nova LDB. Disponível em:

http://www.ccs.uel.br/olhomagico/N16/em questao.htm>. Acesso em 16 nov.

[11] Komatsu, R.S (2006). Um olhar sobre a FAMEMA e o processo pioneiro de implementação da aprendizagem baseada em problemas. Cadernos ABEM, v.2, p.64-72.

[12]Marin, M.J.S. et al. (2010). Aspectos das fortalezas e fragilidades no uso das Metodologias Ativas de Aprendizagem. Rev. Bras. Educ. Med., v.34, n.1, p-13-20.

[13] Mendes, M. \& Guilhermeti, P. (2007). Fragmentação do saber e interdisciplinaridade na formação universitária. Revista eletrônica Lato-Sensu, 1, pp.1-12. Retrieved from http://www.unicentro.br.

[14]Pereira, S.E. (2007). Contribuições para um planejamento educacional em ciências da saúde com estratégias inovadoras de ensino-aprendizagem. Com. Ciências Saúde, v.18, n.1, pp.33-44.

[15]Piccini, R.X; Faleiros, J.J.; Faria, L.H. \& Ceia, M.L. (2001). Disciplina de medicina comunitária: relato de uma experiência inovadora. Rev. Bras. Educ. Med., v.25, n.2, p.64-69.

[16] Ribeiro, M.L. \& Cunha, M.I. (2010). Trajetórias da docência universitária em um programa de pós-graduação em Saúde Coletiva. Interface - Comunic., Saude, Educ., v.14 n.32, pp.55-68.

[17] Stacciarini, J.M.R. \& Esperidião, E. (1999). Repensando estratégias de ensino no processo de aprendizagem. Rev.latinoam.enfermagem, v. 7, n. 5, p. 59-66.

[18] Vignochi, C.; Benetti, C.S.; Machado, C.L.B. \& Manfroi, W.C. (2009). Considerações sobre aprendizagem baseada em problemas na educação em saúde. Rev. HCPA, v.29, n.1, p. $45-50$. 